\section{ENCOURAGING THE NATION TO BE MOUTHAWARE}

In addition to its annual support of Mouth Cancer Action Month, campaign sponsor Denplan has stepped up a gear this year by creating the Blue Lip Selfie campaign with the British Dental Health Foundation.

By encouraging the public and profession to adopt blue lips as a visible sign of support for mouth cancer, it is hoped this positive, interactive approach will significantly boost awareness of the disease.

Organised by the British Dental Health Foundation, Mouth Cancer Action Month promotes the message 'if in doubt, get checked out' in a bid to save thousands of lives through early detection and is supported by hundreds of dental practices nationwide. This year the campaign is encouraging the public to be 'Mouthaware'.

To make it easy for everyone to participate, Denplan has created a special Facebook app at www. bluelipselfie.co.uk. Users can upload and customise selfies with fun blue cartoon lips using the app and share them on the gallery. Denplan is also encouraging people to share their blue lip selfies on social media using the hashtag \#bluelipselfie.

The British Dental Health Foundation has set up a special Blue Lip Selfie JustGiving page for any donations or sponsorship money raised which will be specifically used for mouth cancer support groups: https://www.justgiving. com/bluelipselfie/.

\title{
DO YOU KNOW HOW MANY LAPSED PATIENTS YOU HAVE?
}

Striking figures uncovered in new research have revealed just how few practices are aware of statistical data relating to the day-to-day running of their business. Figures show $60 \%$ of dentists do not know the numbers of lapsed patients in their practice, 40\% don't track where new patients come from and 30\% are unaware how many new patients visit their practice each month.

As the green shoots of economic recovery take hold, Software of Excellence commissioned its latest Whitepaper, Facing the Challenge of New Patient Acquisition, to help guide practices to growth and prosperity.
The business solutions expert has collated data from over 1,500 UK practices giving them a unique insight into what constitutes an efficient practice. One of the most surprising pieces of data highlighted was the extent to which dentists underestimate the need for new patients.

The report has also brought sharply into focus the simple changes practices can implement to improve efficiency and revenue and can now be downloaded for you to read at leisure.

To download Software of Excellence's latest Whitepaper visit www.softwareofexcellence. com/uk/newpatients.

\section{ESSENTIALS OF RESEARCH METHODOLOGY}

The Faculty of General Dental

Practice (UK) is running a twoday course on the Essentials of Research Methodology at the Royal College of Surgeons of England on 5-6 December 2014.

This course is dentistry specific and suitable for research active dentists and dental care professionals (DCPs), as well as newcomers to research in dental and oral health. The lecturers and speakers for the course are eminent members of the academic and research community, and together they comprise a unique programme.

Full details of the programme can be downloaded from the Faculty website: http://www.fgdp.org. $\mathrm{uk} /$ research/research-events.ashx.

\section{STRIKING NEW WEBSITE LAUNCHES AT SHOWCASE}

At this year's BDIA Dental Showcase Dentists' Provident launched a new website for their members, dentists, dental students and financial advisors.

The new site, using their striking new brand colours and photography, allows each audience to navigate easily to their dedicated homepage and, within a few clicks, find the information they are looking for.

New interactive features help members understand the costs and benefits of their plans, third party offers, as well as blog and news pages with information and educational articles for your health and wellbeing. The site also offers quick and easy access to important information about their services.

In addition, there is an area for independent financial advisors providing marketing resources and essential information to assist them in reviewing their client's cover. Finally, there is a section dedicated to foundation dentists and dental students, including the new student plan. This section contains specific support and information for both groups.

To see the site for yourself go to www.dentistsprovident.co.uk.

\section{IS YOUR PRACTICE SAFE FROM FIRE?}

Did you know that your dental practice is required by law to have a fire risk assessment?

It is essential under government legislation (The Regulatory Reform [Fire Safety] Order 2005) that every company has adequately trained fire wardens on duty. ARC Fire Training Services can train your staff, fulfilling your legal and moral responsibilities and helping to protect your business and contracts.

Eric Dempsey of ARC Fire Training Services has over 30 years' experience in emergency response management, including 28 years with the UK Fire $\mathrm{At}$ Rescue Service as an operational fire officer, instructor/training and safety officer. ARC will come to you and train your staff on: specialist equipment training; specific training for on-site risks; prac tical hot fire training (facilities permitting); fire team leader - emergency response leader training; setting up a command point; cordons; team briefings; dynamic risk assessment; safe approach; snatch rescues where life is threatened; initial first aid; hand over to senior manager; and specific site plans tailored to your workplace.

For more information visit http:// www.arcfiretrainingservices.co.uk or call 01516050744.

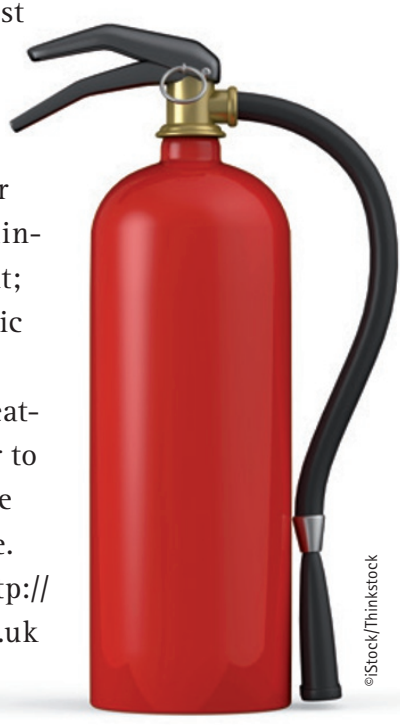

